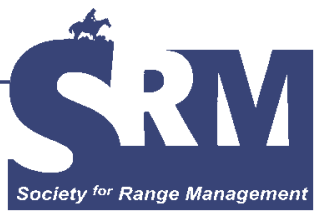

\title{
Open Spaces, Working Places
}

\section{Local government programs can slow loss of rangelands-but only if urban and ranching interests find ways to work together.}

\section{By Jessica Resnik, George Wallace, Mark Brunson, and John Mitchell}

$\mathrm{P}$

rivate rangeland near many Western cities is disappearing rapidly under an onslaught of suburban and "ranchette" developments. As the "peopling of the New West" continues unabated, alarms have been raised on two fronts: by rural citizens and conservation groups troubled by the loss of agricultural production and biological diversity, and by urban interests that lament the loss of open space and recreation opportunity. Some counties and cities are taking steps to slow the rate of rangeland conversion by acquiring farms and ranches for use as open space, but that won't do much to ease rural concerns unless concerted cooperative efforts are made to both reduce potential conflicts over recreational and agricultural land uses and maintain rangeland landscapes that serve as more than just scenic backdrops for suburban lifestyles.

\section{Public Working Landscapes}

Many local governments are coping with the impacts of rapid growth by creating open space and natural area systems. Nationwide, state and local voters approved $75 \%$ of the 217 open space ballot initiatives between 2004-2006, creating new taxbased revenue streams for the purchase of open space and natural areas or conservation easements. ${ }^{2}$ This phenomenon has happened at a time when numerous other new tax proposals have been soundly defeated.

Since the City of Boulder, Colorado, became one of the first local governments to start protecting open space as a way to counter the impacts of development and preserve the aes-

This article has been peer reviewed. thetic and ecological values of natural areas, other municipalities and counties have followed suit along Colorado's Front Range. Among the major motivations behind such programs are reducing growth that does not pay for the infrastructure it requires; protecting scenic vistas; safeguarding ecosystem integrity, wildlife habitat, and environmental services; maintaining rural character; and meeting the increasing demand for outdoor recreation near urbanizing areas.

The City of Fort Collins and Larimer County, Colorado, began their natural areas and open lands programs in the 1990s. Like other jurisdictions, they have begun to include "working landscapes" that allow traditional agricultural and other productive activities to continue as part of their Open Space/Natural Area programs.

\section{Rangeland Open Space and Natural Areas}

The same development pressure that has created a demand for open space has reduced the area of private rangeland and pastureland available for livestock forage. This makes it more difficult for livestock producers to lease grazing lands to complement their own operations, a common practice in areas where land prices are high and drought can limit forage production on non-irrigated lands. The value and viability of livestock operations almost always include both base properties owned in fee and acres available for leasing. Livestock producers who wish to remain in production - especially the part-time producers that are increasingly common in areas where human populations are expanding-but who are unable to lease sufficient land to supplement their deeded lands, may not remain financially viable and consequently succumb to development pressure themselves. 


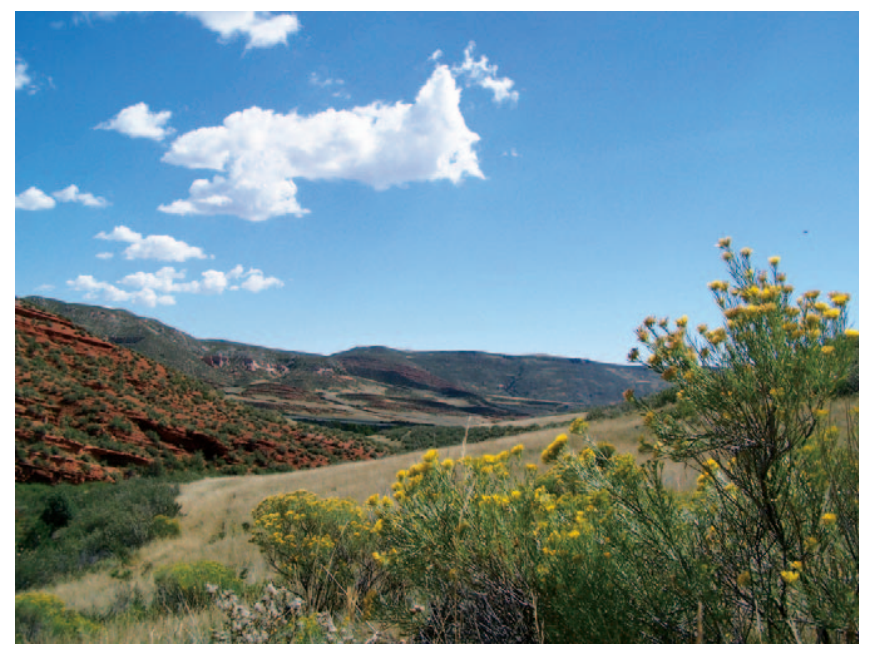

18,764-acre Soapstone Prairie Natural Area acquired by the City of Fort Collins Open Space and Natural Areas Program in 2004. Livestock grazing will continue on Soapstone when it opens to the public for recreation in 2009. Photo by Fort Collins Natural Areas Program.

Public working landscapes provide one way of reversing this trend. As the term implies, land remains in production that would otherwise have been sold for development. A type of multiple-use/multiple-benefit Open Space and Natural Area, they strike a balance between economic, ecological, recreational, historical, and other social needs. They contribute to community goals like minimizing the loss of agricultural land and water, or separating communities that might otherwise grow together. ${ }^{3}$ Allowing grazing to continue on lands that had evolved under herbivory and drawing on local livestock producers to help with the management of such lands is both appropriate and practical as it can utilize local knowledge and traditions. New part-

\section{Sidebar 1. Folsom Grazing Association}

Folsom Grazing Association currently possesses the grazing leased for the 18,764-acre Soapstone Prairie Natural Area owned by the City of Fort Collins Open Space and Natural Areas Program. The 12 members of this grazing association in 2006 collectively owned 10,725 fee-simple and leased 4,660 acres in northern Colorado. By providing summer pasture for the livestock owned by the grazing association, the City of Fort Collins effectively preserved an additional 15,385 acres of open space by helping to keep the land owned and leased by Folsom members in agriculture. Additionally, all but 2 of the 12 members are at least 3rd generation Colorado natives and all have a history of family farming and ranching on the Front Range. Five separate families are direct descendants of homesteaders in northern Colorado. Supporting local ranching operations not only helps base properties stay in agriculture but helps preserve the local agricultural tradition and rural character, goals identified in both the City of Fort Collins Natural Areas Program and Larimer County Master Plans. nerships between livestock producers and local government Open Space and Natural Area programs seem to provide an innovative and beneficial option for producers in areas with considerable development pressure and diminishing rangelands (Sidebar 1).

Preservation of working rangelands by local government programs provides a host of recreational, educational, and conservation benefits (Sidebar 2). At a time of increasing energy costs and greater interest in local and sustainable production of healthy food, ${ }^{4}$ Open Space and Natural Area programs could help make locally raised "conservation meats" accessible to the communities that support them. Additionally, renting pasture for livestock grazing provides a local revenue stream for Open Space and Natural Area programs. It can even provide an opportunity for young producers with less capital and land to move into ranching by utilizing local open space lands, especially where such arrangements impose fewer financial constraints. This is similar to how the Province of Saskatchewan, Canada, has used agricultural land banking to help young producers get started. ${ }^{5}$

While these Colorado experiences provide a positive example for other communities to follow, significant challenges must be surmounted before public working landscapes can become viable land-use options for rangeland conservation across the western United States. These challenges-along with some intriguing opportunities - fall into 5 general categories: financial, institutional, political, managerial, and social.

\section{Show Me the Money}

A key challenge faced by local governments is finding the money to acquire and manage ranch lands that might become public working landscapes. State laws differ in terms of how they allow local governments to raise or obtain funds for open space projects. At one end of the spectrum is Colorado, where the Great Outdoors Colorado Trust Fund uses a portion of state lottery proceeds for preserving, protecting, and enhancing wildlife, parks, rivers, trails, and open spaces. Since 1994, Great Outdoors Colorado has awarded nearly half a billion dollars for 2,100 such projects across the state.

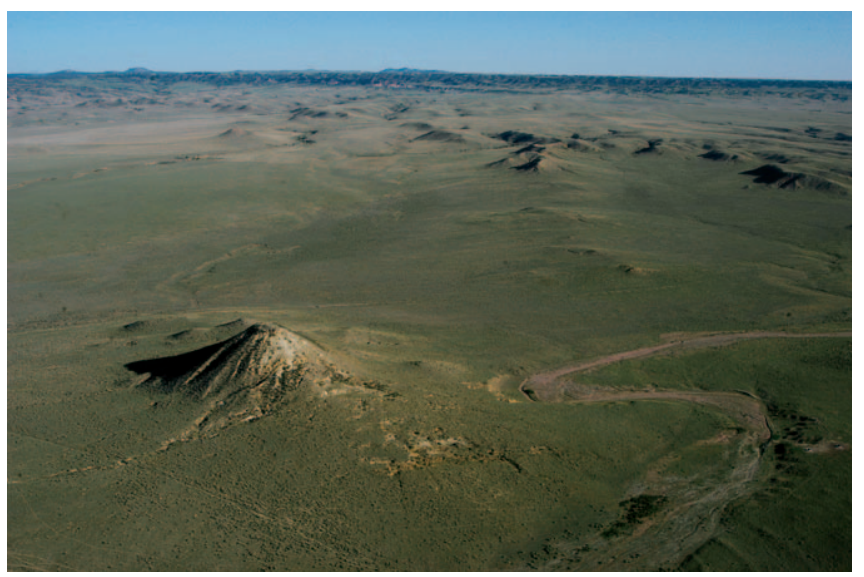

Soapstone ranch looking northwest towards foothills. Photo by John Mitchell. 


\section{Sidebar 2. Northern Colorado's Laramie Foothills Mountains-to-Plains Project}

A collaborative effort using City of Fort Collins' Building Community Choices sales tax revenues, Larimer County's 0.25\% Help Preserve Open Spaces sales tax, lottery funds from Great Outdoors Colorado, and funds from The Nature Conservancy resulted in the purchase or protection (using conservation easements) of more than 50,000 contiguous acres connecting foothills and plains along the Colorado-Wyoming border. This project is an example of how good working relationships among local governments and funding agencies can effectively preserve and connect a diversity of ecosystems. Larimer County, which owns the 13,500-acre Red Mountain Ranch, and the City of Fort Collins, which owns the 18,764-acre Soapstone Prairie Natural Area, have decided that continuing grazing on their properties is essential for maintaining rangeland health and local tradition.

Conversely, in another state where population growth has spread into areas where ranching is a major land use, Utah voters defeated a $\$ 150$ million open-space 2004 bond issue backed by a sales tax increase of $1 / 20$ th of a cent. The Utah Legislature has on multiple occasions rebuffed efforts to allow local governments to use voter-approved sales tax increases to pay for open space acquisition. Ranches that are prime candidates for acquisition do not come cheap, either. Although Utah municipalities can issue bonds backed by property taxes for open space acquisition and several have done so, individual cities' and towns' purchasing power may not be great enough to acquire large properties.

A Wyoming study found that ranches having wildlife habitat and scenic vistas command higher prices per acre than those which primarily possess agricultural production capacity, even though the latter may be closer to town. ${ }^{6}$ Such properties may be out of the financial reach of most local



Cattle grazing on the Red Mountain Ranch. The Nature Conservancy and Larimer County Open Lands recently closed on the purchase of the 15,300-acre ranch north of Fort Collins, Colorado. Red Mountain Ranch is a centerpiece of the Laramie Foothills: Mountains to Plains project. Photo by Larimer County Open Lands Program. governments except when sellers are able to take advantage of tax incentives for using conservation easements or for making "bargain sales"-when a donor sells property to a charitable organization for less than its fair market value.

However, where communities are able to dig deep into their pockets to protect open space, ranch lands are part of their plans. For example in Pima County, Arizona, voters in 2004 approved a $\$ 174.3$ million bond issue for fee purchase and conservation easements to protect wildlife habitat, scenic landscapes, riparian areas, water quality, and open space. Included among the properties acquired are 3 large ranches that held both fee land and public grazing leases: the A-7, Bar V, and Rancho Seco. This combination of 18,144 acres in fee and 46,582 acres in state and federal leases, along with the proximity to both the city of Tucson and to nearby protected areas such as the Buenos Aires National Wildlife Refuge and Las Cienegas National Conservation Area, make these areas prime candidates for management as public working landscapes.

\section{Other Funding Alternatives}

There are other alternatives to fee purchase and conservation easements for creating working landscapes. Arizona has been a leader in using existing institutional structures to create new opportunities for conservation in areas threatened by development. Many of these lands include livestock grazing as uses. Although subject to a constitutional mandate that state trust lands be managed to maximize revenue for public schools and institutions (as in most western states), the Arizona Preservation Initiative in 1996 established a process whereby state lands can be reclassified for conservation and subsequently leased or sold at auction for that purpose. $\mathrm{Mu}-$ nicipalities can apply for state matching grants to make such purchases easier. Intergovernmental or public/private partnerships, such as a unique arrangement among the Bureau of Land Management (BLM) and various entities in southeast Arizona, provide another creative approach where funds may not otherwise be available (Sidebar 3).

Also in 1996, the voters of Colorado amended their constitution to establish a Stewardship Land Trust within the

\section{Sidebar 3. The Bureau of Land Management} and the Empire Ranch Foundation

An alternative arrangement in Arizona is found at the Empire and Cienega ranches southeast of Tucson. The BLM acquired the property in 1998 at the urging of the Pima and Santa Cruz county commissions who wished to stave off almost certain exurban development in a biologically diverse landscape of woodlands and grasslands. The BLM manages the land for multiple benefits in partnership with the non-profit Empire Ranch Foundation, under a plan developed collaboratively over a 5-year period with a voluntary association of local citizens, ranchers, conservation organizations, recreationists, and state agencies. 
3-million acre land base administered by the State Land Board to benefit state trusts. By 2005, 107 parcels totaling 295,700 acres had been incorporated into the Stewardship Trust. ${ }^{7}$ The purpose of Colorado Stewardship Trust lands is to protect long-term productivity and sound stewardship instead of maximizing returns to the trusts. These lands are not guaranteed to remain as open space forever because an $80 \%$ majority vote of the Land Board commissioners can remove them from the Stewardship Trust rolls. However, provisions are in place within the Land Board to work with local communities that want to assure the permanency of the stewardship designation to allow purchase of these lands or purchase of conservation easements through a competitive bid process.

\section{Institutional Know-How}

The option of managing cooperatively with another agency or non-governmental organization can address the primary institutional challenge that local governments may not have the expertise to manage a large landscape for multiple benefits. For example, the A-7 ranch now owned by Pima County, Arizona, was held for several years by the City of Tucson, which consistently lost money on the operation and never figured out how to fit a ranch into its governmental operations. ${ }^{8}$ The City of Eagle, Idaho, which in spring 2006 began a process to acquire 2,000 acres of the Boise foothills from the BLM to protect recreation access and scenic vistas, has no parks and recreation department. ${ }^{9}$ In contrast, Larimer County, Colorado, hired staff with range management experience and have worked closely with livestock producers to capture local knowledge. Where funding limits this as an option, partnering with another agency or non-governmental organization could help.

Cooperative management with public land agencies can also be seen as offering new communication channels for local governments, which often perceive a lack of consultation and information flow when agencies such as the BLM or Forest Service take actions on public lands that affect nearby communities. This approach fits well with the Department of Interior's Cooperative Conservation Initiative, which encourages voluntary, incentive-based approaches to enhancing, restoring, and protecting land, water, air, and wildlife resources on public and private lands nationwide.

\section{Talking Politics}

Political challenges arise whenever decisions are made about the allowable mix of uses and benefits to be realized from publicly owned rangelands. These conflicts can be diminished when responsibility belongs to local governments; still, any community large enough to acquire a working landscape will have significant numbers of citizens who do not support livestock grazing on public lands - or even acquisition of lands somewhat distant from an urban center when local city services are seen as inadequate. Planning processes must address these concerns. Such efforts may prove less problematic at city or county levels because national or regional organizations with hard-line positions against specific land uses typically lack the legal standing at the local level that they enjoy in planning for federal rangelands. This is not to say conflicts will not exist, nor that community consensus will find that all large open space tracts are suitable for designation as working landscapes.

Many Americans believe that lands characterized as "protected areas" should not have commercial uses such as ranching. In fact, when the Grand Staircase-Escalante National Monument was declared, visitor support for livestock grazing in the monument declined in an apparent case of "designation effect." ${ }^{10}$ When cities and counties are the landowners and managers, this effect will depend largely on values held by the local community. Previous studies have found that local users of Forest Service multiple-use lands in western Colorado are more supportive of grazing that those from outside the region. ${ }^{11}$

In parts of the West, a large political hurdle must be cleared before working landscapes can even be acquired. While local governments have several options including fee purchase for protecting open space, community efforts to do so often lead to controversy as landowners and developers assert that they alone control use of their property. While many residents would agree with such assertions, communities have in fact always controlled land use by means of zoning to protect the greater good of the community. An opportunity exists to help citizens understand how they might benefit from a working landscape approach: maintaining historic land uses, protecting against the loss of biodiversity and critical habitats, providing recreation access, and even increasing the value of properties located nearby as local governments along the Colorado Front Range and some intermountain areas have begun to do.

\section{Local Government Politics}

As a result of a series of laws and policy changes enacted over the past half-century, livestock grazing now co-exists with recreation, cultural resource management and biodiversity protection on most federal and state protected lands. The advent of local government Open Space and Natural Areas systems is the next chapter in the relationship between public lands and grazing. Range management by local governments and their new partners is a somewhat uncharted area that has new variables and challenges, including a different group of recreational and other users, a complex set of management objectives to which producers must adapt, and a new framework for governance and decision making.

Local Open Space and Natural Areas are utilized for public recreation by users who live nearby, are repeat users and who have more direct access to policy makers. It is important to note that cities and counties are more directly accountable to those taxpayers who finance the acquisition and management of protected areas than are federal or state governments who often serve a more distant general public. This can make management of Open Space and Natural Areas subject to inconsistent and inexperienced decisions by local city councils, 




Citizen tour of rangelands managed by local governments in northern Larimer County, Colorado. Photo by Larimer County Open Lands Program.

boards of county commissioners or their appointed boards and commissions-especially for younger Open Space and Natural Area programs. On the other hand, this new form of governance could be more flexible and responsive to informed public opinion as it matures.

\section{Multiple Needs Management}

The compatibility of grazing and recreation on Open Space and Natural Area areas, which are typically smaller than Forest Service or BLM units, must be of particular concern to managers and grazing permittees alike- both parties must share a new set of nontraditional management objectives. Objectives like invasive species management and leaving forage for certain species of wildlife are shared already, but others like cultural resource protection, biodiversity enhancement, interpretation, and education may be new for some livestock producers-especially those who belong to private grazing associations. Likewise, producers' needs for fencing, water sources to disperse utilization, predator control, and other range management practices can be controversial among some urban constituents and new territory for open space or natural area managers. Enhancing the compatibility of grazing and recreation, however, will be central to the success of most working landscapes.

\section{Grazing and Recreation Compatibility}

Information regarding grazing and recreation on Forest Service lands, wilderness areas, and national monuments provide some guidance for managers needing to maintain both of these uses. Studies have shown that expectations of visitors to rangelands affect their acceptance of grazing. The majority of recreationists feel grazing is conditionally acceptable if accompanied by good range management, but they respond negatively when grazing interferes with recreation experiences. Acceptance also varies by the location of where the encounters occur. Even so, some aspects of grazing on open, working landscapes can enhance recreation experiences. ${ }^{12}$ Conflict between recreation and grazing can be based either on goal interference (where the physical presence of one interferes with the ability of the other to accomplish their goals, eg, cattle blocking a trail, entering a campsite, or visitors ha- rassing cattle) or based on differences in social values (people may dislike all grazing on public lands or feel that efforts to protect endangered species are too restrictive). ${ }^{13}$

Understanding the distinction between these two types of conflict is important since management actions are most effective when the underlying causes of conflict are understood. Research suggests that where goal interference is present, zoning (including infrastructure placement and selected visitor management techniques) is an effective management strategy. Educational programs are more effective when dealing with social values conflicts. ${ }^{14}$ Educational programs might require that managers help visitors understand more about range management (including its history) and range conditions. ${ }^{15}$

The potential for conflict might also be reduced by providing opportunities for field tours, ride-alongs when cattle are gathered or moved between pastures, and volunteer opportunities to monitor vegetation, fix fences, or install water systems to protect wetlands.

\section{Social Acceptance}

The final set of challenges and opportunities are social. As noted above, citizens can object to sharing recreation settings with commercial land uses. Ranching may be incompatible with motorized recreation except under carefully controlled circumstances. Moreover, many ranchers are uncomfortable sharing their grazing lands with others. That is one reason why ranch owners often choose not to allow for-profit recreation uses that could diversify and improve their income flows. While most public lands grazing permittees do share their allotments with recreationists and other users, one attraction of the open land/working landscape concept is that they may have more opportunity to participate in planning and decisions regarding type, location, and amount of recreation and other activities that will occur when livestock are present. Additionally, they can provide input as to the way grazing is presented to the public.

Livestock producers generally hesitate to try out new management options-whether a new grazing system or a different decision-making arrangement-because the margin between profit and loss is so thin and the costs of a mistake can be high. Public working landscapes are clearly an innovative land use, so the majority of producers may prefer not to be the first to make them work. But rangeland innovators do exist. In fact, in a study of "cutting edge" ranchers in Utah, a major reason given for making changes in ranch operations was to demonstrate to the public that sound ranching is not only possible but desirable. ${ }^{16} \mathrm{~A}$ defining characteristic of working public landscapes is that they would offer ranchers and other range managers a chance to help citizens understand the potential benefits of carefully managed livestock grazing for the maintenance of healthy rangelands.

\section{Summary}

Exurban development-ie, low-density housing (<64 homes/ square mile) within a landscape dominated by native vegeta- 


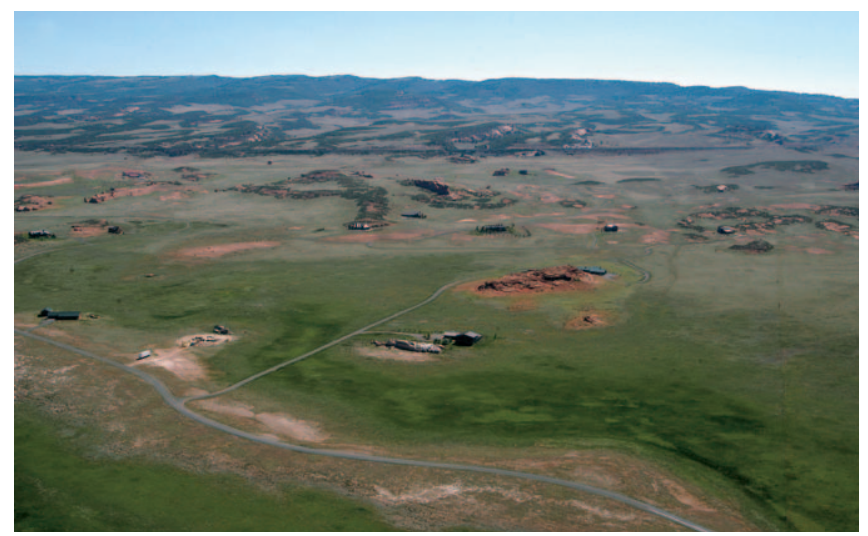

Ranchettes in foothills southeast of Laramie, Wyoming. Photo by John Mitchell.

tion-is now the fastest-growing form of land use in the US, covering nearly $25 \%$ of the area of the lower 48 states. ${ }^{17}$ The most rapid change is occurring in the Southwest and Rocky Mountains states where it typically involves conversion of ranchland to residential property. The advent of working landscapes managed by local government open space programs but leased to livestock producers can be seen as an innovative way to partially offset the loss of rangelands. It also creates a situation calling for a unique balance of grazing and recreational use while maintaining open space for other values sought by the local community. Examples of the partnerships which make these working landscapes possible, and some the challenges they face, are available throughout the West.

All things considered, programs to create and manage open space in rapidly growing parts of the New West offer a new and challenging opportunity to both range managers and local counties and municipalities. Management niches provided by working landscapes that fall under the stewardship of local communities will provide new opportunities for rangeland professionals, advancing our ability to integrate ecology, economics, and social science as a key concept in sustainable development.

Authors are Graduate Student, College of Natural Resources, Colorado State University, Fort Collins, CO 80523-1480, jresnik@warnercnr.colostate.edu (Resnik); Associate Professor, Department of Natural Resource Recreation and Tourism, Colorado State University, georgew@warnercnr.colostate.edu (Wallace); Professor, Department of Environment and Society, Utah State University, Logan, UT 84322-5215, mark.brunson@usu. edu (Brunson); and Rangeland Scientist, USDA Forest Service, Rocky Mountain Research Station, Fort Collins, CO 805262098, jemitchell@fs.fed.us (Mitchell).

\section{References}

1. Riebsame, W. E. [ED.]. 1997. Atlas of the new West: portrait of a changing region. New York, NY: W. W. Norton \& Co. 192 p.

2. The Trust for Public Land and Land Trust Alliance. 2005. LandVote 2005: Americans invest in parks and conservation. 12 p. Available at: www.lta.org/publicpolicy/ landvote_2005.pdf. Accessed 8 September 2006.

3. Larimer County. 2001. Larimer County open lands master plan. Parks and Open Lands Department, Larimer County, Colorado. Available at: http://www.co.larimer.co.us/parks/ openlands/master_plan.pdf. Accessed 8 September 2006.

4. Nabhan, G. P. 2002. Coming home to eat: the pleasures and politics of local foods. New York, NY: W. W. Norton \& Co. $306 \mathrm{p}$.

5. Strong, A. L. 1979. Land Banking: European reality, American prospect. Baltimore, MD: The Johns Hopkins Univ. Press. 312 p.

6. Bastian, C. T., D. M. McLeod, M. J. Germino, W. A. Reiners, and B. J. Blasko. 2002. Environmental amenities and agricultural land values: a hedonic model using geographic information systems data. Ecological Economics 40:337-349.

7. Colorado Division of Wildlife. 2005. Colorado State Trust Lands. Available at: http://wildlife.state.co.us/NR/ rdonlyres/92E6A12D-921E-4824-A2D5-E82659410103/0/ statetrustlands.pdf. Accessed 8 September 2006.

8. Devine, D. 2002. 11 April 2002. Uneasy ranch hands. Tucson Weekly. Available at: http://www.tucsonweekly.com/gbase/ Currents/Content?oid=oid:45254. Accessed 8 September 2006.

9. Moeller, K. 2006. 7 June 2006. Eagle begins effort to acquire 2,000 acres in Foothills. Idaho Statesman, June 7.

10. Palmer, L. 2001. Recreation, livestock grazing, and protected resource values in the Grand Staircase-Escalante National Monument [M.S. thesis]. Logan, UT: Utah State University. $116 \mathrm{p}$.

11. Johnson, L. C., G. N. Wallace, and J. E. Mitchell. 1997. Visitor perceptions of livestock grazing in 5 US wilderness areas. International Journal of Wilderness 3(2):14-20.

12. Wallace, G. N., J. E. Mitchell, and M. D. Wells. 1996. Visitor perceptions about grazing on a Forest Service cattle allotment. Fort Collins, CO: United States Department of Agriculture, Forest Service, Rocky Mountain Forest and Range Experiment Station. No. RM-RP-321. 12 p.

13. Brunson, M. W., And B. S. Steel. 1996. Sources of variation in attitudes and beliefs about federal rangeland management. Journal of Range Management 49(1):69-75.

14. Manning, R. E. 1999. Studies in outdoor recreation. Corvallis, OR: Oregon State Univ. Press. 314 p.

15. Mitchell, J. E., G. N. Wallace, and M. D. Wells. 1996. Visitor perceptions about cattle grazing on National Forest land. Journal of Range Management 49(1):81-86.

16. Didier, E. A., And M. W. Brunson. 2004. Adoption of range management innovations by Utah ranchers. Journal of Range Management 57:330-336.

17. Hansen, A. J., R. L. Knight, J. M. Marzluff, S. Powell, K. Brown, P. H. Gude, And K. Jones. 2005. Effects of exurban development on biodiversity: patterns, mechanisms, and research needs. Ecological Applications 15: 1893-1905. 